\title{
IMPROVING NUTRIENT AND WATER-HOLDING CAPACITY IN SANDY REGOSOL BY APPLYING LOCALLY AVAILABLE AMENDMENTS
}

\author{
Punitha Premanandarajah and Komathy Prapagar \\ Faculty of Agriculture, Eastern University, Sri Lanka.
}

\begin{abstract}
A pot experiment wàs carried out at the agronomy farm Eastern University, Chenkalady, Batticaloa, to study the impact of locally available organic manures on the mutrient and water holding capacity of sandy regosol. Three organic sources integrated with different rates of recommended chemical fertilizer and were evaluated with sole recommended chemical fertilizer. Twelve treatments including integrated organic manures with chemical fertilizers at different rates, sole organic manure treatment, sole chemical fertilizer treatment at recommended level and at half the recommended level and no fertilizer control. Completely Randomized Design with 3 replicates was used as layout. Soil analysis for available soil nitrogen content, moisture retention, cation exchange capacity and organic matter content were carried out at planting (red onion), just before top dressing and at the time of harvest.
\end{abstract}

Integration of organic manure with chemical fertilizer favorably influenced nitrogen availability in soil. Among the organic manures poultry manure had the greatest influence on soil available nitrogen

content. Organic manures increased the soil moisture retention capacity, with tank silt(Organic deposit in dry muc.) ranking first. Soil cation exchange capacity was favorably influenced by organic manure application. Cation exchange capacity was higher in tank silt treatment than other organic sources. Cation exchange capacity was increased from planting stage to just before top dressing and decreased at harvest stage. The soil organic matter content also followed a similar trend.

Key words: cation exchange capacity, partially burned paddy husk, poultry manure, soil organic matter content, tank silt

\section{INTRODUCTION}

Soils are irreplaceable and valuable source for mankind, where decomposition of organic manures occurred recycling nutrients from soils to plants. Sandy regosol soil predominating the coastal belt of Batticaloa district is very low in plant nutrients especially nitrogen and poor in other soil fertility components due to its poor retention capacity. Brady (1990) stated that sandy soils have lower cation exchange capacity than clay soils because the coarse textured soils are low in both clay and humus content. 
Nitrogen is one of the essential nutrients for plants and its practical management as the major element in intensive agriculture for plant production is an important aspect. Plants respond quickly to soil available nitrogen. Nitrogen absorption adequately increases photosynthesis, vegetative growth and eventually yield. Addition of inorganic fertilizers to improve the nitrogen status of sandy soil will not be economical and environmentally friendly due to its heavy leaching nature. Insufficient nitrogen more commonly limits crop yield than any other nutrient deficiency, yet nitrate $\left(\mathrm{NO}_{3}^{-}\right)$leaching from agricultural areas is a wide spread ground water pollutant (Schonbeck, 2004). Thus managing nitrogen so as reap the desired yield without causing nitrate pollution is real challenge. The nitrogen status can be achieved by the addition of locally available organic compounds, which favours plant growth mainly by improving the retention capacity of regosol soils. Peech (1965) reported that increase in organic matter content in the sandy soils increase the cation exchange capacity. Integrated use of organic manures and chemical fertilizers increases fertilizer use efficiency. Integrated plant nutrient system (IPNS) attempts to keep a balance between crop removal and nutrient addition to the soil. Any IPNS practice has to be economically sound and socially acceptable. In Batticaloa district along the riverbed the salvenia and other water loving plants are deposited, decomposed and formed into a black colour organic compound like compost. These components are locally available along the riverbeds as dry mud during dry seasons and are referred as tank silt. Farmers in Kaluthavala area mostly use tank silt as organic manure. Burnt paddy husk is another highly available amendment in Batticaloa district, which improves nutrient level of sandy regosol effectively without any side effect Okan et al. (2005). It is well known that poultry manures are anothor source of nutrients and are highly available in Batticaloa district. Poultry manures contain about 1.67\% nitrogen (Limtong and Pachaya, 1996).

Therefore understanding the recovery of fertilizer nitrogen under particular soil and environmental condition and the process of potential nitrogen loss is important to adopt protection measures to enhance the nitrogen reeovery of crops and to reduce the potential nitrogen losses and ground water pollution. So, estimation of the efficient utilization of locally available organic manures and their impact on nitrogen retention, ion and water retention capacity through integrated plant nutrient system (IPNS) is essential.

The objective of the present study was to compare the available nitrogen, cation exchange and moisture retention in regosol after mixing with different organic materials.

\section{MATERIALS AND METHODS}

\section{Location}

A pot experiment was carried out at the Agronomy farm of Faculty of Agriculture. Eastern University, vantharumoolai, Chenkalady located in Batticaloa district. The region falls within the agro-ecological zone 
of low country dry zone (DL2). The mean annual rainfall ranges from $1400 \mathrm{~mm}$ to $1680 \mathrm{~mm}$ and temperature varies from $30^{\circ} \mathrm{C}$ to $33^{\circ} \mathrm{C}$. The soil contained $91.8,4.9$ and 3.3 percent sand, silt and clay respectively and classified as sandy regosol (Survey department, 1998). The organic matter content was $1.32 \%$.

\section{Experimental design}

By using three locally available organic materials and chemical fertilizers the following treatments were prepared. Three organic sources, Partially burnt paddy husk (P.H), Tank silt (T.S) and poultry manure (P.M) integrated with different rates of chemical fertilizer and were evaluated with sole recommended chemical fertilizer. There were twelve treatments including integrated organic manures with recommended and half recommended level of chemical fertilizers; namely,

$\mathrm{T} 1=$ Paddy husk $(\mathrm{P} . \mathrm{H})$

$\mathrm{T} 2=$ Paddy husk + recommended level of chemical fertilizer

T3= Paddy husk + half the recommended level of chemical fertilizer

T4= Tank silt (T.S)

$\mathrm{T} 5=$ Tank silt + recommended level of chemical fertilizer

$\mathrm{T} 6=$ Tank silt + half the recommended level of chemical fertilizer

$\mathrm{T} 7=$ Poultry manure (P.M)

T8 $=$ Poultry manure + recommended level of chemical fertilizer

T9= Poultry manure + half the recommended level of chemical fertilizer

$\mathrm{T} 10=$ Recommended level of chemical fertilizer

$\mathrm{T} 11=$ Half the recommended level of chemical fertilizer

$\mathrm{T} 12=$ Control

\section{Pot experiment}

Disturbed surface soil sample (Sandy regosols) was collected up to a depth of $20 \mathrm{~cm}$ from agronomy farm, Eastern University. Soil was filled into plastic pots leaving $10 \mathrm{~cm}$ from the top of the pot. Treatments were arranged in a Complete Randomized Design with three replicates. Organic amendments used in the research work (iank silt, poultry manures and partially burnt paddy husk) were mixed thoroughly with the soil as per treatment two weeks prior to planting to allow decomposition.

\section{Fertilizer application}

Basal fertilizer application was done one day before planting at the rate of $100 \mathrm{~kg} /$ ha Urea, $100 \mathrm{~kg}$ tripplc super phosphate and $50 \mathrm{~kg}$ muriate of potash per hectare. Top dressing was done 3 weeks after planting with urea and muriate of potash at the rate of $100 \mathrm{~kg} / \mathrm{ha}$ and $25 \mathrm{~kg} /$ ha respectively for all treatments. 


\section{Soil sampling and analysis}

Soil samples were collected at 3 stages from each pot at the time of planting, just before top dressing and at the time of harvest. All soil samples were air dried before estimation.

Cation exchange capacity, available 1itrogen content, moisture retention and organic the matter content of each and every samples were determined by the following methods. Cation exchange capacity by leaching method (Rhoades, 1982), available nitrogen content by Kjelhal method (Gupta, 1999), moisture retention by the gravimetric method (Majumda and Singh, 2000) and organic the matter content by titrimetric method (Walkely and Black, 1934).

\section{RESULTS AND DISCUSSION}

\section{Nitrogen content of soil}

The experimental result revealed that the soil nitrogen content was significantly influenced by treatments (Figure I). Addition of organic manures increases the nitrogen status of soil. Vitosh et al.(1997) reported that addition of organic matter increases the nitrogen status of soil. Available nitrogen content was significantly influenced by integrating organic matter with chemical fertilizer at different rates. Among organic matter tested poultry manure ranked first and was followed by tank silt and paddy husk. This may be due to high N content of poultry manure than other organic sources. Poultry manure is rich organic manure since solid and liquid excreta are excreted together resulting in no urine loss (Amanullah et al., 2007).

Addition of organic matter with recommended chemical fertilizers increased the soil nitrogen content than sole chemical fertilizer treatment $\left(\mathrm{T}_{1}, \mathrm{~T}_{4}, \mathrm{~T}_{7}\right.$ and $\left.\mathrm{T}_{10}\right)$. The increase might be due to the organic manures that help to reduce the leaching loss of nitrogen from soil and act as a binding agent for nutrients. Chemical fertilizer has less nitrogen than chemical fertilizer organic matter combination. The organic matter may release nitrogen to soil this may be the reason for high nitrogen content in chemical fertilizer organic matter combination. Among the combination organic matter with recommended level of chemical fertilizer ranked first than half recommended chemical fertilizer combination.

The progressive release of the nutrient elements by mineralization of organic matter is essential for plant nutrition in traditional system of cropping where little or no inorganic fertilizers are used, the fact that the release from organic matter mineralization is progressive is very important as it reduces losses by leaching. Losses of soluble forms by leaching depend mainly on the rate of decomposition of organic malter (Charreau, 1978). 
Blondel (1971) experienced that the level of mineral nitrogen are low in organic matters, but mineralization of nitrogen appears to have been induced by the plants themselves and addition of organic matter significantly increased mineralization by $36 \%$ for soil. The fraction of humus seems to have special importance for mineralization of nitrogen and nitrogen nutrition of crops in the sandy coarse loamy soils of the dry tropical zone.

\section{Effect of organic amendments in moisture content of soil}

The results pertaining to the moisture content of soil indicated that organic manure significantly increased the soil moisture content than control (Table I). This might be due to the soil aggregation. In addition, organic amendments have high specific area, which promotes water-holding capacity (Brady, 1974). Addition of organic matter leads the soil to hold water 20 times of its weight and significantly improve the moisture retention properties especially of sandy soils (Gupta, 2003). Among Organic manures tank silt recorded the highest moisture content $(17.31 \%)$. This may be due to that the organic matter was in decomposed form. Soils incorporated with partially burnt paddy husk and poultry manure also showed high moisture retention (14.4\% and $14.1 \%$ respectively) than control (11.1\%). Beneficial effects on the soil when applying poultry manure at proper rates include higher organic content of the soil, which increases its water-holding capacity and helps sustain plants through seasons of drought (Jack et al., 2004). These statements strengthened the above results.

\section{Cation exchange capacity (CEC) of soil}

The analysis of the post harvest soils for cation exchange capacity revealed that the soils treated with organic amendme, its increased cation excahange capacity than control and there is significant difference in cation excahange capacity with different organic amendments due to different C:N ratio (Table II). Since organic matter provides most of the exchangeable sites, most of the soil available cations are thereforc associated with it. By incorporating organic matter it is possible to have cation excahange capacity to the range of 300-1400 $\mathrm{cmol}(+) / \mathrm{kg}$. It will increase soil CEC and contributed $20 \%-70 \%$ of cation excahange capacity in many soils (Gupta, 2003).

The statistical scrutiny of the results revealed that the tank silt significantly increased the cation excahange capacity to 61.77 than other treatments. This may be due to that the tank silt was in partially decomposed or easily decomposable form than other organic manures. Greenland, (1972) discussed that organic matter normally has about 200 meq of carboxyl groups per $100 \mathrm{~g}$. 


\section{Changes in CEC with time}

The result indicates that the organic manure significantly increasing the cation excahange capacity of soil from stage I to stage II than control (Table III). The results clearly indicated that there was a clear relationship between organic matter content and cation exchange capacity of the soil. At the basal dressing stage ( 3 weeks after planting) cation excahange capacity and organic matter content was significantly higher in all treatments than at the begining and at harvesting Bande et al., (2002) confirmed that soils with high in clay content, and especially those high in organic matter, tend to have higher cation excahange capacity than those low in organic matter content. Cation exchange capacity of the soil at harvesting stage was significantly lower than initial stage.

\section{CONCLUSION}

Organic matter enhanced the soil nitrogen level. The increase was greater for poultry manure treated soil than tank silt and partially burnt husk treated soils. Each type of organic matter enhanced the moisture retention in sandy regosols. Tank silt showed higher water retention than others. From initial stage to harvest stage the moisture retention was increased significantly in all treatments. Cation exchange capacity was increased by the addition of organic materials and was higher in tank silt treated soils. Cation exchange capacity and organic matter content was increased from initial stage to second stage and then reduced in third stage.

\section{REFERENCES}

Bande, A.A., James, B. and Meisinger, J.J.,(2002) Basic Principles of Soil Fertility II: Soil Properties. University of Maryland College Park. Collage of Agricultural and natural resources.Blondel, D., (1971). Cited from FAO. 1978, Soil Bulletin 27. Organic materials as fertilizers.

Brady Nyle. C., (1990). The nature and properties of soils. 10 $0^{\text {th }}$ Edition. Macmillan Publishing Company. USA.

Brady, N. C., (1974). The nature and properties of soils. Macmillan Publishing Company. USA. P.623. Charreau, C (1978). Organic matter and biochemical properties of soil in the dry tropical zone of West Africa. In: FAO 1978, Soil Bulletin 27. Organic materials as fertilizers.

Donahue, R.L., Miller, R. and Shickluna, J.C.M (1983). An introduction to soils and plant growth.

$5^{\text {th. }}$ edi. Prentice-Hall, Inc. Englewood Cliffs, N.J. USA. p. 148-151.

Greenland, D. J (1972). Biological and organic aspects of plant nutrition in relation to need research on tropical soils. Com.Sem. On Tropical Soils. IITA.

Gupta, P.K (1999). Soil, Plant, Water and Fertilizer Analysis. Agro Botanical, IVE 176, J.N. Vyas Nagar.New Delhi. 
Gupta, P.K., (2003).Ahand book of Soil, Fertilizers and Manures. $2^{\text {nd }}$ enlarged edition. Agribios (India).pp. 6-229. Jack, C. Boles, J., Karl Van Devender, John Langston and Angela Rieck., (2004). Environmental ConcernsDry Poultry Manure Management- MP 358 University of Arkansas. UA Cooperative Extension Service.

Limtong, P. and Pachaya, T., (1996). Poly and application of organic fertilizers for soil improvement.

Thailand. Country features. Agro Chemicala News in Brief. Vol XIX, No. 2, April-Jun. 1996.pp.129-143.

Majumdar, S.P. and Singh, R.A., (2000). Analysis of soil physical properties. Agrobios Publications. India. 5:79. Mohamad Amanullah, M., Somasundaram, E., Vaiyapuri, K. and Sathyamoorthi, K. 2007. Poultry manure to crops $-\Lambda$ review. Agric. Rev, 28 (3): 216-222.

Okan, Paul B., Ogeh, Joseph S. Amalu, Uche C. (2005). Effect of rice husk ash and phosphorus on some properties of acid sands and yield of okra. Communications in Soil Science and Plant Analysis, 36: $7,833-845$.

Peech, M., (1965). Exchange activity. Agronomy 9 : 905-913.

Rhoades, J.D., (1982). Cation Exchange Capacity. Methods of soil analysis. Part 2. Am. Soc. Agron. Soil. Sci. Soc. Am-Madison, Wisconsis.pp 149-157.Schonbeck, M., (2004).Ecological sound nitrogen management: One researchers educated guess. Alchemy institute.

Survey Department, (1998). National Atlas, Colombo, Sri Lanka.

Vitosh, M.L., Lucas, R.E and Silva, G.H., (1997). Long term effects of fertilizers and manures on corn yield, soil C and other soil chemical properties in Michigan. In: Role of soil organic matter in temperate Agro ecosystems.Paul, E.A., Paustican, K., Ellioth, E.T. and Cole, C.V. (eds.). CRS press, Inc.8:129-138.

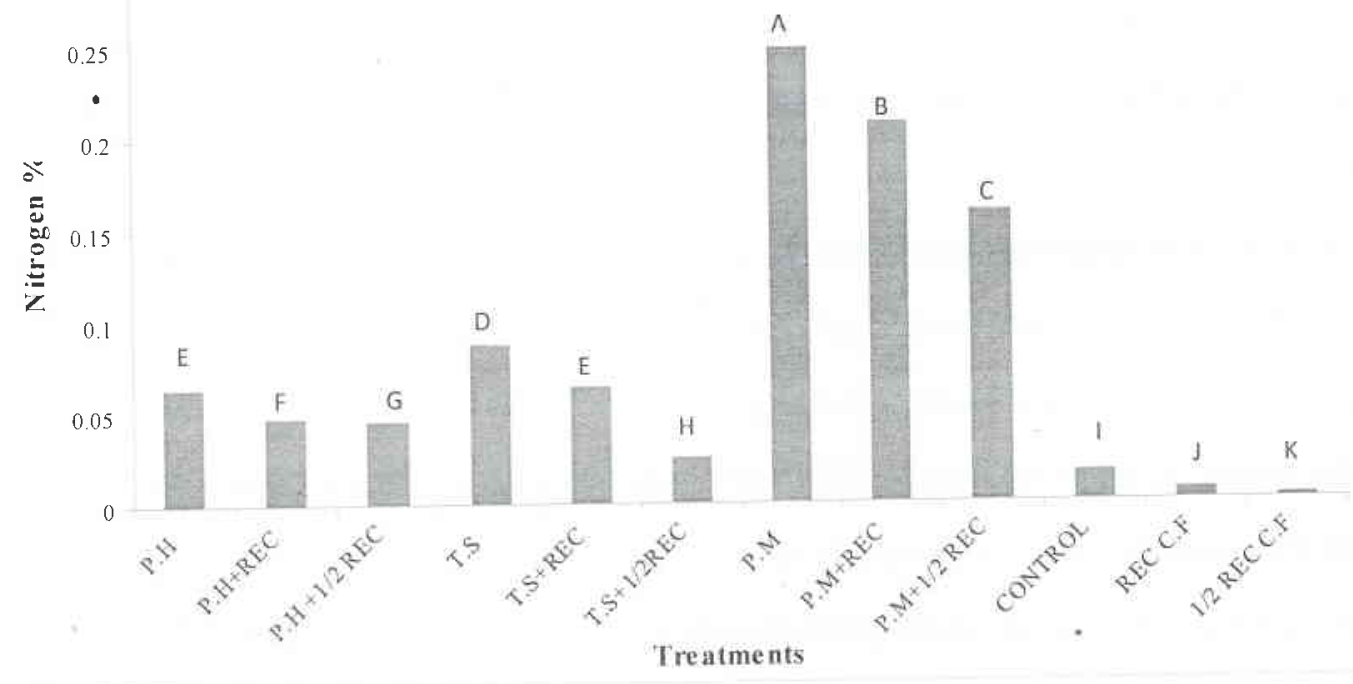

Figure1: Nitrogen content in soil with different treatments

(P.II- Paddy husk; T.S- Tank silt; P.M- Poultry manure; Rec = Recommended level of chemical fertilizer) 


\begin{tabular}{ll}
\hline Table 1. The mean moisture content $(\%)$ of soil at harvesting \\
\hline P.H + Rec & $10.10^{\mathrm{i}}$ \\
P.H $+1 / 2 \operatorname{Rec}$ & $12.88^{\mathrm{g}}$ \\
P.H & $20.32^{\mathrm{a}}$ \\
T.S $+\operatorname{Rec}$ & $16.46^{\mathrm{d}}$ \\
T.S $+1 / 2 \operatorname{Rec}$ & $17.48^{\mathrm{c}}$ \\
T.S & $17.99^{\mathrm{b}}$ \\
P.M $+\operatorname{Rec}$ & $9.82^{\mathrm{j}}$ \\
P.M $+1 / 2 \operatorname{Rec}$ & $14.45^{\mathrm{f}}$ \\
P.M & $18.03^{\mathrm{b}}$ \\
Rec & $7.45^{\mathrm{k}}$ \\
$1 / 2$ Rec & $10.97^{\mathrm{h}}$ \\
Control & $14.80^{\mathrm{e}}$ \\
\hline
\end{tabular}

(P.H- Paddy husk; T.S- Tank silt; P.M- Poultry manure; Rec = Recommended levcl of chemical fertilizer)

Table 2. Cation exchange capacity $(\mathrm{cmol}(+) / \mathrm{Kg})$ of Locally available

\begin{tabular}{lc}
\multicolumn{2}{c}{ amendments at harvesting } \\
\hline Treatments & Cation exchange capacity \\
\hline P.H + Rec & $17.78^{\mathrm{d}}$ \\
P.H $+1 / 2 \operatorname{Rec}$ & $16.32^{\mathrm{e}}$ \\
P.H & $14.89^{\mathrm{f}}$ \\
T.S + Rec & $42.94^{\mathrm{a}}$ \\
T.S $+1 / 2 \operatorname{Rec}$ & $39.65^{\mathrm{b}}$ \\
T.S & $38.85^{\mathrm{c}}$ \\
P.M + Rec & $6.74^{\mathrm{g}}$ \\
P.M $+1 / 2 \operatorname{Rec}$ & $5.38^{\mathrm{j}}$ \\
P.M & $4.85^{\mathrm{k}}$ \\
Rec & $6.05^{\mathrm{h}}$ \\
$1 / 2$ Rec & $5.99^{\mathrm{i}}$ \\
Control & $0.94^{1}$
\end{tabular}


Table 3: Effect of organic residues on periodical change in $\mathrm{CEC}(\mathrm{cmol}(+) / \mathrm{Kg})$ and organic matter content $(\%)$ in soil

\begin{tabular}{|c|c|c|c|c|c|c|}
\hline \multirow[t]{2}{*}{ Treatments } & \multicolumn{2}{|c|}{ At planting } & \multicolumn{2}{|c|}{ At top dressing } & \multicolumn{2}{|c|}{ At harvesting } \\
\hline & CEC & OM & CEC & OM & $\mathrm{CEC}$ & $\mathrm{OM}$ \\
\hline T.S + Rec & $39.88^{c}$ & $2.47^{c}$ & $102.49^{a}$ & $4.27^{\mathrm{a}}$ & $42.94^{b}$ & $3.32^{b}$ \\
\hline $\mathrm{T} . \mathrm{S}+1 / 2 \operatorname{Rec}$ & $37.64^{c}$ & $2.42^{\mathrm{c}}$ & $93.72^{a}$ & $4.54^{\mathrm{a}}$ & $39.65^{b}$ & $3.41^{b}$ \\
\hline T.S & $36.84^{\mathrm{c}}$ & $2.38^{\mathrm{c}}$ & $37.96^{\mathrm{b}}$ & $4.62^{\mathrm{a}}$ & $38.85^{a}$ & $3.58^{b}$ \\
\hline P.H + Rec & $20.69^{b}$ & $1.86^{\mathrm{c}}$ & $42.71^{\mathrm{a}}$ & $1.93^{b}$ & $17.78^{\mathrm{c}}$ & $2.09^{x}$ \\
\hline P.H + 1/2 Rec & $18.62^{b}$ & $1.94^{b}$ & $38.43^{\mathrm{a}}$ & $1.81^{c}$ & $16.32^{\mathrm{c}}$ & $2.18^{a}$ \\
\hline P.H & $12.32^{c}$ & $2.01^{b}$ & $13.64^{b}$ & $1.97^{\mathrm{c}}$ & $14.89^{\mathrm{a}}$ & $2.26^{\mathrm{a}}$ \\
\hline P.M + Rec & $26.24^{b}$ & $2.41^{\mathrm{c}}$ & $43.73^{a}$ & $3.41^{\mathrm{a}}$ & $6.74^{c}$ & $2.85^{b}$ \\
\hline $\mathrm{P} . \mathrm{M}+1 / 2 \mathrm{Rec}$ & $25.12^{b}$ & $2.62^{\mathrm{c}}$ & $39.86^{\mathrm{a}}$ & $3.76^{\mathrm{a}}$ & $5.38^{c}$ & $2.89^{b}$ \\
\hline P.M & $3.82^{c}$ & $2.88^{c}$ & $4.14^{b}$ & $3.94^{\mathrm{a}}$ & $4.85^{a}$ & $2.97^{b}$ \\
\hline Rec & $5.99^{a}$ & $1.59^{\mathrm{a}}$ & $6.00^{a}$ & $1.59^{\mathrm{a}}$ & $6.05^{a}$ & $1.61^{a}$ \\
\hline $1 / 2 \operatorname{Rec}$ & $4.87^{c}$ & $1.59^{\mathrm{a}}$ & $5.21^{b}$ & $1.59^{\mathrm{a}}$ & $5.99^{\mathrm{a}}$ & $1.60^{\mathrm{a}}$ \\
\hline Control & $1.61^{\mathrm{a}}$ & $1.60^{\mathrm{a}}$ & $1.01^{b}$ & $1.60^{\mathrm{a}}$ & $0.94^{\mathrm{c}}$ & $1.62^{\prime}$ \\
\hline
\end{tabular}

(P.H- Paddy husk; T.S- Tank silt; P.M- Poultry manure; Rec = Recommended level of chemical fertilizer) 